\title{
Acidification Power (AP) Test and Similar Methods for Assessment and Prediction of Fermentation Activity of Industrial Microorganisms
}

\section{Test acidifikační síly (AP) a př́ibuzné metody pro stanovení a prèedpověd' fermentační aktivity prümyslových mikroorganismu}

\author{
Karel SIGLER \\ Institute of Microbiology, Academy of Sciences of the Czech Republic, Vídeňská 1083, 14220 Prague 4 / Mikrobiologický ústav, \\ Akademie věd České republiky, Vídenská 1083, 14220 Praha 4 \\ e-mail: sigler@biomed.cas.cz
}

Reviewed paper / Recenzovaný článek

Sigler, K.: Acidification power (AP) test and similar methods for assessment and prediction of fermentation activity of industrial microorganisms. Kvasny Prum. 59, 2013, No. 7-8, p. 204-208

A brief survey is given of the methods for determining the vitality and fermentation vigor of microorganisms (yeast, bacteria) used in brewing, baking and milk processing industries, with special reference to methods based on proton and/or ion relationships between the cells and the environment. Most of these methods are based on proton extrusion rate (acidification power) under different conditions and cellular traits connected with it, such as intracellular $\mathrm{pH}$.

Sigler, K.: Test acidifikační síly (AP) a příbuzné metody pro stanovení a předpověd fermentační aktivity průmyslových mikroorganismů. Kvasny Prum. 59, 2013, č. 7-8, s. 204-208

Je podán stručný přehled metod používaných pro stanovení vitality a fermentační aktivity mikroorganismů (kvasinek, bakterií) používaných $v$ pivovarském, pekařském a mlékárenském průmyslu, se zvláštním zaměřením na metody založené na protonových a/nebo iontových poměrech a rovnováhách mezi buňkami a okolím. Většina těchto metod je založena na měření rychlosti výstupu protonů z buněk (acidifikační síle) stanovené za různých podmínek, a na důležitých buněčných charakteristikách s ní spojených, jako je vnitrobuněčné $\mathrm{pH}$.

Sigler, K.: Test der Azidifikationskraft und die zur Bestimmung und Vorhersage der Fermentationsaktivität von industriellen Mikroorganismen angewandte ähnliche Methoden. Kvasny Prum. 59, 2013, Nr. 7-8, S. 204-208

Im Artikel wird einen kurzen Überblick über die zur Bestimmung der Vitalität und Fermentationsaktivität von in der Brau-, Backwaren- und Milchindustrie angewandten Mikroorganismen (Hefe, Bakterien) mit einem besonderem Fokus auf die Basis Protonen- und/ oder lonenverhältnissen gegründete Methoden und auf dem Gleichgewicht zwischen Zellen und Milieu beschrieben. Meist werden die auf Grund des Messens der Protonenaustrittsgeschwindigkeit (Azidifikationskraft) aus den Zellen gegründete Methoden verwendet. Die Protonenaustrittsgeschwindigkeit (Azidifikationskraft) wurde unter verschiedenen Bedingungen und mit den auf wichtigen Zellcharakteristiken, z. B. der Innenzellwert pH gegründet.

Keywords: proton extrusion, acidification power test, cell vitality, industrial microorganisms

Klíčová slova: vypuzování protonů, test acidifikační síly, vitalita buněk, průmyslové mikroorganismy

\section{INTRODUCTION}

Many microorganisms (yeasts, lactic acid bacteria) acidify outer medium during fermentative processes that take place, e.g., during dough leavening, cheese or wine making and during beer brewing. The surge of external acidification taking place on resuspending cells in a new medium or adding a metabolic substrate belong to the so-called "early events" that occur before any measurable change of the substrate, constitute an immediate response of the culture exposed to a new environment (Quain, 1988) and have been shown to be very useful as significant indicators of the physiological status of the culture and key events necessary for normal fermentation (Riis et al., 1995). Transport studies performed in the 1980's (Sigler et al., 1981a,b; Sigler et al., 1983; Pascual et al., 1983) showed that the ability of yeast cells to excrete acidity from several sources (proton extrusion by membrane $\mathrm{H}^{+}$-ATPase, $\mathrm{H}^{+} / \mathrm{K}^{+}$ exchange, production of $\mathrm{CO}_{2}$ and organic acids) is a strictly controlled process that reflects very closely the metabolic vigor of the cells or, in other words, their vitality under given conditions. The results of these studies led to the elaboration by Opekarová and Sigler (1982) of the acidification power (AP) test (see also Sigler and Höfer, 1991a,b; 1997), which provided a fast and methodologically simple means of assessing how various factors (previous history of cell culture, stress factors such as starvation, temperature, osmotic pressure, freeze drying, chemical stress imposed by components of fermentation media, preservatives and others) affect the ability of cells to utilize a sugar substrate such as glucose and, consequently, perform successful and technologically profitable fermentation. Still more importantly, the test made it possible to predict the outcome of the fermentation process conducted with a certain batch of cells, and thus prevent sluggish or stuck fermentations.

Because it offered an easy-to-perform assay for assessing and above all, predicting the metabolic vigor of wet starter cultures to be used for industrial purposes, the acidification power test became subsequently widely used in the brewing (Fernandez et al., 1991, 1993; Iserentant et al., 1996; Kara et al., 1988; Lawrence, 2002; Peddie et al., 1991; Šusta et al., 1984; Van Zandycke et al., 2001) and baking industries (Collar et al., 2005; Higgins et al., 2001; Vincent et al., 1999), in wine-making (Malfeito-Ferreira et al., 1990) and in other biotechnology branches, e.g. for determining the freshness of rice (Shindo et al., 2000). It was also employed for evaluating the metabolic prowess of immobilized (Shen et al., 2003; Wackerbauer et al., 2002) and freeze-dried yeast (Peddie et al., 1991), of newly generated baker's yeast strains (Higgins et al., 2001) and non-saccharomycete yeasts such as Zygosaccharomyces rouxii (Yoshikawa et al., 1995).

The test has had several advantages compared with previously used fermentative power assays (e.g. Pearce, 1969); it is fast (the result can be achieved within 60-80 min; Gatto et al., 1993) and requires only a basic equipment (a centrifuge and a temperaturecompensated $\mathrm{pH}$ meter) available in most food industry laboratories. Because of its simplicity and satisfactory reproducibility, it has been used as a rejection criterion for assessing the technological quality of starter cultures and its use extended from brewery to cider production, bakery products manufacture and cheese making based on lactic acid bacteria (Gatto et al., 1993; International Dairy Federation Guideline, 1995; Rechinger and Siegumfeldt, 2002; Riis et al., 1995; Semjonovs et al., 2004) and other microorganisms. 


\section{PROCESSES INVOLVED IN ACIDITY EXTRUSION}

The various processes involved in both spontaneous and substrate-induced acidification of yeast suspensions have been analyzed in detail by Sigler and Höfer (1991a). In yeast, extracellular acidification occurs under both aerobic and anaerobic conditions and is fuelled by a variety of glycolytic as well as respiratory substrates, both endogenous and exogenous. Respiratory substrates under conventional conditions (in a medium containing dissolved oxygen at normal partial pressure) cause very low acidification due to the oxygen limitation that sets in very quickly under these conditions. Under intensive aeration the acidification caused by ethanol is fully comparable with that caused by glucose. Even without any exogenous substrate, addition of $\mathrm{H}_{2} \mathrm{O}_{2}$ concentrations $>10 \mathrm{mmol} / \mathrm{L}$ to aerated derepressed yeast suspension causes a comparable acidification that persists until necessary endogenous substrates are consumed in respiratory processes. This acidification is suspended by $\mathrm{H}^{+}$-ATPase inhibitors and is associated with concomitant $\mathrm{K}^{+}$influx (Sigler and Höfer, 1991a,b).

The participating processes include $\mathrm{CO}_{2}$ production from fermentative or respiratory processes, extrusion of protons by the plasma membrane $\mathrm{H}^{+}$-ATPase, efflux of acidic metabolites such as succinate or lactate, and $\mathrm{K}^{+} / \mathrm{H}^{+}$exchange. The contributions of individual processes to the overall acidification course and intensity appear to depend strongly on measurement conditions (substrate and cell concentration, aeration, etc.). Thus Myers et al. (2005), on the basis of the lack of effect of $\mathrm{H}^{+}$-ATPase inhibitors such as diethylstilbestrol and vanadate, reported that glucose-supported acidification in aerated yeast suspension is almost entirely due to $\mathrm{CO}_{2}$ production by the cells, the $\mathrm{H}^{+}$-ATPase playing no role in the process. Sigler et al. (1991b), on the other hand, found under their experimental conditions a strong inhibition of acidification when $\mathrm{H}^{+}$-ATPase was inhibited by diethylstilbestrol and asserted that that the enzyme plays an important part in the acidification process.

Machnicka et al. (2004) described a set of $A C l$ genes apparently responsible for signaling amino acid deprivation in yeast cells in which part of the Krebs cycle intermediates have to be used for amino acid synthesis via the glyoxylate cycle. Mutants in these genes excrete protons instantaneously on being suspended in unbuffered water in the absence of any external carbon source, excreting citrate, aconitate, succinate, fumarate or malate and reaching external $\mathrm{pH}$ levels below that produced on glucose addition.

\section{AP TEST}

The test is very simple. In the initial part, $\mathrm{pH}$ is measured 10 min after suspending the cells in water without exogenous sugar. This spontaneous acidification power, given by the $\Delta \mathrm{pH}_{10}$ value, reflects the metabolism of endogenous substrates and $\mathrm{CO}_{2}$ production. In the second part, the cell suspension is supplied with glucose, which causes an additional strong acidification of the external medium that is gauged by measuring the $\mathrm{pH}$ value of the suspension after another $10 \mathrm{~min}-\Delta \mathrm{pH}_{20}$. The magnitude of this glucose-induced $\mathrm{H}+$ efflux reflects the fermentative ability of the yeast while the sum of $\Delta \mathrm{pH}_{10}$ and $\Delta \mathrm{pH}_{20}$, termed the acidification power (AP) reflects the overall vitality of the cells (Opekarová and Sigler, 1982). The intensity of the substrate-induced acidification is controlled by external $\mathrm{pH}$. If this control is abolished by keeping the pHout artificially constant, e.g. in a $\mathrm{pH}$-stat, the net proton efflux increases up to 100-fold. According to Castrillo et al. (1995), it is then independent of the buffering capacity of culture medium. In a chemostat culture, it is closely associated with the nitrogen uptake rate.

Sigler et al. (1981a) showed in laboratory yeast strains that the extent of acidification observed in aqueous yeast suspension after glucose addition strongly depends on cell concentration, increasing with rising suspension density and reaching a constant level at a cell concentration of about 50-60 g cell pellet/l. Janda and Kotyk (1985) noted that the specific rates of many processes in diverse microorganisms, i.e. the rates referred to a single cell, drop markedly with increasing suspension density, leveling off at a certain cell concentration characteristic for the given microorganism and the type of metabolic or transport process. The signal substance suppressing the activity of individual cells at higher cell concentrations was suggested to be $\mathrm{CO}_{2}$, which has been known to have multifarious affects on cells (Das et al., 1990; Jones and Greenfield, 1982; Mitz, 1979; Oura, 1977).

Hence, the AP test has to be performed at these saturation cell concentrations because otherwise small differences in cell concentration in individual samples (unavoidable if the cells are used as slurries or wet pellets) can lead to large differences in AP. Except for special cases (the vitaltitration of Rodrigues et al., 2003), the cell concentration used in most studies to ensure saturation conditions was, in terms of the industrially most suitable use, equal to a minimum of $50 \mathrm{~g}$ packed yeast pellet per $1 \mathrm{l}$.

The dependence of the AP value on the concentration of glucose has likewise a saturation character, and the sugar concentration used should be high enough to ensure essentially constant $\mathrm{H}+$ efflux irrespective of minor variations in sugar level. In this respect, different studies were performed under widely varying conditions, the glucose concentrations ranging from 1.7 to $9 \%$, the latter value being proposed by Opekarová and Sigler (1981) as truly saturating.

Gabriel et al. (2008) optimized the AP by storing the yeast slurry at $2^{\circ} \mathrm{C}$ under beer. Under these conditions the AP remains constant for up to 6 days. Sample equilibration to room temperature and washing in deionised water ensured that the final yeast pellet kept its AP for up to $6 \mathrm{~h}$ at room temperature under water and the AP test did not need to be performed immediately after yeast collection. The maximum acidification produced by given yeast was determined in a sample containing $\geq 5 \%$ glucose and $\geq 1.5 \mathrm{~g}$ yeast wet weight. Cell flocculation and/or sedimentation that can distort APT results can be prevented by stirring the sample at $\geq 200 \mathrm{rpm}$. The lowest AP of yeast cropped from cylindroconical tanks was displayed by the first cropped fraction. Variations in pitching yeast vitality and their effect on the outcome of a brewery fermentation can be masked by variations in pitching rate, wort composition, ambient conditions in the cylindroconical tanks and other factors.

\section{ACIDIFICATION POWER AND FERMENTATION VIGOR}

\subsection{Brewing industry}

The $\Delta \mathrm{pH}_{10}$ value has been suggested to be related to the growth potential of a given pitching yeast lot (Kara et al., 1988). When the AP test is performed at intervals during the fermentation process, the evolution of this initial endogenous $\mathrm{H}+$ extrusion was found to be identical to the evolution of glycogen level in the cells (Imai, 1999). Although it was found by some authors to be less reproducible than the subsequently measured glucoseinduced and mostly $\mathrm{H}^{+}$-ATPase-mediated proton efflux, this stage is essential to equilibrate the $\mathrm{pH}$ of the cells (Van Zandycke et al., 2001).

On the other hand, the glucose-induced acidification value $\Delta \mathrm{pH}_{20}$ is an indicator of the glycolytic flux rate (Mathieu et al., 1991; Imai et al., 1994). In an overall AP value of brewery yeast of, say, 2.5 the $\Delta \mathrm{pH}_{10}$ is typically around 0.5 , the $\Delta \mathrm{pH}_{20}$ being around 2 (see. e.g., Kara et al., 1988).

\subsection{Baking industry}

In baking industry, acidification power was shown to be inversely related to the specific volume of breads and the degree of dough cohesiveness in fresh pan breads doped with microbial transglutaminase (Collar et al., 2005).

Two types of baker's yeast are used in the modern baking industry: strains with efficient maltose metabolism optimized for use in unsugared dough and osmotolerant strains specialized for use in sweet doughs with sugar concentrations of up to $30 \%(\mathrm{w} / \mathrm{w})$ of flour. A cycling between growth on galactose and growth on maltose was found to enrich the yeast culture in efficient maltose utilizers. The maltose utilization phenotype was determined by the AP test (Higgins et al., 2001).

\subsection{Milk processing - lactic acid bacteria}

Lactic acid bacteria (LAB) are widely used as starter cultures for fermentation of milk, vegetables, and meat. Gatto et al. (1993) modified the AP test for use with the lactic acid bacteria and tested its applicability on dried and rehydrated Streptococcus cremoris/S. lactis and Lactobacillus acidophilus. The assay was found to be considerably faster and methodologically sim- 
pler than, e.g., the classical Pearce test based on small scale fermentation in milk (Pearce, 1969). The spontaneous no-substrate acidification with lactic acid bacteria is negligible; the requisite 10-min period was retained, then lactose was added and the AP value was calculated as a difference between the starting $\mathrm{pH}$ of 6.3 and the $\Delta \mathrm{pH}_{20}$ measured 10 min after sugar addition. The AP values of the bacteria were markedly affected by cell washing and rehydration at different temperatures, by the temperature at which the AP test was performed, and was much higher with lactose than with sucrose as acidification substrate. A positive correlation was found between the AP value and the results of the Pearce test. With frozen, frozen and stressed as well as lyophilized Lactobacillus delbrueckii ssp. bulgaricus cells the AP test was found to be more sensitive than the standard acidification test or flow cytometry (Riis et al., 1995).

Rechinger and Siegumfeldt (2002) prepared Lactobacillus delbrueckii ssp. bulgaricus cultures with different viable cell counts by mixing frozen and lyophilized cells in different ratios. The AP values correlated well with the degree of vitality. This linear correlation between AP values and the Pearce test data was not confirmed by Riis et al. (1995) who, however, found a considerable impact of temperature stress on the AP values. According to the authors, the cell damage caused by freeze drying, freezing and thawing of frozen cultures does not seem to influence the ability of the bacteria to spontaneously utilize their endogenous carbohydrates while it reduces the ability of the bacteria to utilize exogenous sugars. Both flow cytometry and classical fermentation of reconstituted skim milk failed to reveal these effects.

\section{OTHER TESTS BASED ON PROTON OR ION RELATIONSHIPS IN CELLS}

A number of studies were devoted to assessing the merits and shortcoming of the AP test. Thus Willetts et al. (1997) and Seward et al. (1996), when testing the vitality of cider yeast grown in the presence of different alcohols, showed the AP value to be a sensitive indicator of vitality superior to, e.g., the adenylate charge values. In studies on immobilized brewery yeast, the AP was a useful measure of cell vitality but was reported to suffer in some cases from low reproducibility (Wackerbauer et al., 2002). Since the AP test should serve primarily as a rejection criterion for fermentation-incompetent cells, it should be employed with caution for, e.g., distinguishing between several highly fermentation-competent strains having high AP values (Iserentant et al., 1996). In this situation the predictive power, i.e. the key to how the cells will behave when exposed to future stress (re-pitching, high-gravity environment, etc.) is lost because cells in a momentary good condition - replete with endogenous substrates, with high adenylate charge, etc. - will, unless exposed to a stress of sufficient intensity and duration, not provide any cue as to their possible behavior when stressed. The methods stated to be suitable for these cases are, e.g., the assay of intracellular $\mathrm{pH}$ of cells by staining with fluorescein diacetate or the ICP method of Imai et al. (1994) using another fluorescent dye, 5 (and 6)-carboxyfluorescein, at low external $\mathrm{pH}$. Both these methods require a spectrofluorimeter, however.

Sigler et al. (1981b) monitored the response of glucose-supplied $S$. cerevisiae suspensions to an alkali challenge of different magnitude. Under the experimental conditions used, the cells were able to fully restore the normal external $\mathrm{pH}$ after alkalinization to $\mathrm{pH} 10$ but failed to do so at pH 11-12. Rodrigues et al. (2003) used a similar alkaline challenge to assess the vitality of cropped and pitching brewery yeast, monitoring the time interval necessary for the substratefree yeast slurry to return from $\mathrm{pH} 10$ to $\mathrm{pH}$ 6.5. These "vitaltitration" (VT) values, which agreed well with the acidification power test data, were shown to correlate well with fermentation rate, wort attenuation and beer foam stability.

In a detailed study (Mathieu et al., 1991), the magnitude of AP drop during the first day of brewery fermentation correlated with the fermentation performance of lager yeast. A short (15-min) contact of cells with full wort, or hop extract and tannic acid, i.e. components of the trub (the sediment at the bottom of the fermenter consisting of hot and cold break material and dead yeast), but not with filtered wort, i.e. under conditions simulating yeast pitching, brought about the same AP drop and was used as a predictive measure of fermentation performance. The AP after the predictive treatment can be used as rejection criterion; the rejection value is yeast strain dependent (Mathieu et al., 1991).
The AP value was also found to correlate with the fermentation quotient $\mathrm{QArCO}_{2}$ (Šusta et al., 1984) and the specific oxygen uptake rate (Kara et al., 1988). During the storage of different yeast strains, AP provides reliable information about the overall fermentative ability of yeast and the inter-strain AP differences correspond to the differences in the ability of yeast to reduce vicinal ketones (Fernandez et al., 1991). The AP test also proved to be well suited for the determination of the ability of brewer's yeast to tolerate acid washing (Fernandez et al., 1993).

Some authors used AP as a reference to other methods of measuring yeast viability and/or vitality, e.g. by staining with methylene blue, alkaline methylene blue, methylene violet, safranin O-methylene blue double staining or electrochemical measurement of yeast vitality via reduction of 2,3,5-trimethyl-1,4-benzoquinone to the corresponding hydroquinone or flow cytometry with fluorescein diacetate (Jespersen and Jakobsen, 1994; Sami et al., 1994; Smart et al., 1999; Tsukatami et al., 2003). The concentration of proteinase A excreted from yeast cells into beer during fermentation was found to be closely related to the vitality of pitching yeast cells gauged by acidification power (Kondo et al., 1999).

The test was also highly instrumental in turning the attention of both researchers and technologists to $\mathrm{pH}$, both extra- and intracellular, as an indicator of physiological state of some microorganisms. In the meantime, efforts were made to increase its sensitivity and flexibility by using, instead of the extracellular $\mathrm{pH}$ change, titratable acidity (Iserentant et al., 1996), cumulative acidity (Patino et al., 1993) or the time necessary for the return of a yeast culture/suspension to nearly optimal $\mathrm{pH}$ after an alkaline challenge (so-called vitaltitration; Rodrigues et al., 2003). Yu et al. (2011) modified the AP assay by measuring the proton efflux rate (PER, in $\mathrm{nmol} \mathrm{H}^{+} /$min.mg cell dry weight) after leaving the spontaneous acidification proceed unmeasured for $20 \mathrm{~min}$ and measuring the $\mathrm{pH}$ only after adding glucose to cell suspension acidified to $\mathrm{pH} 4.0$ by hydrochloric acid. Other related methods included, e.g., the use of intracellular $\mathrm{pH}$ as a metabolic indicator using suitable fluorimetric or other techniques (Imai et al., 1994); a microtitre plate modification of the AP test was used for a speedy estimate of the metabolic prowess of baker's yeast (Vincent et al., 1999). The rising awareness of the significance of not only protons, but ionic homeostasis in general, brought yeast vitality assessment methods that use as the key parameter, e.g., the rate of magnesium release during wort fermentation (Mochaba et al., 1997, 1998). A detailed whole-genome analysis of the significance and role of various ions in yeast cells, the so-called ionome, has been published by Eide et al. (2005).

\section{SOME FACTORS AFFECTING THE ACIDIFICATION RATE}

Among the factors affecting the acidification rate are, e.g., high ethanol concentration and high wort osmolarity encountered during high gravity brewing (HGB).

Osmotic pressure was shown to affect strongly the rate of acidification in S. cerevisiae (de Maranon et al., 2001). Hyperosmotic shock caused by both permeant and impermeant solutes lowers the acidification rate; a total inhibition of the process takes place when the size of the osmotically shrunken cells reaches $50 \%$ of initial cell volume. The osmotic pressure exerted by permeant solutes (glycerol, xylitol, sorbitol) is about $20 \mathrm{MPa}$ while impermeant solutes (PEG $600)$ exert an equal effect at $8.5 \mathrm{MPa}$.

Using the AP test, yeast from high-gravity (HGB) fermentation was found to be unsuitable for re-pitching since the cell membrane is adversely affected by the high ethanol concentration (Van Zandycke et al., 2001). The proton extrusion rate was found to be markedly inhibited during high gravity and very high gravity brewing of $S$. pastorianus, the inhibition being stronger at later stages of HGB and VHG wort fermentation and being given to a large extent by high ethanol concentration ( $Y u$ et al., 2011). Likewise, the negative effects of HGB were found to be unconnected with osmotic effects of high sugar concentrations up to $25 \%(\mathrm{w} / \mathrm{v})$ and have been attributed entirely to ethanol concentration (Hammond et al., 2001). They were reported to be largely mitigated by the yeast peptide complex (YPC) obtained by alcoholic extraction of yeast (Debourg, 2002).

Sigler et al. (2009) mimicked HGB conditions by using standard wort supplemented with sorbitol to determine the net effect of wort osmolarity without the influence of ethanol. They described the effect 
of osmolarity alone on fermentation course, wort attenuation, yeast flocculation and acidification power.

The effect of acid washing on the acidification was studied by Fernandez et al. (1993).

During the production of cider from apple juice, a number of higher alcohols are produced by the cells that may pose considerable chemical stress. Although the yeast strains used in cider fermentations are as a rule ethanol-tolerant, high ethanol concentrations also can have deleterious effects on cells. The presence of alcohols $(10 \% \mathrm{v} / \mathrm{v}$ ethanol, $0.05 \%$ hexan-1-ol or $0.25 \% 2$-phenylethanol) during the aerobic growth and fermentation of cider yeast reduced both the growth rate and the AP value (Seward et

\section{REFERENCES}

Castrillo, J.I., De Miguel, I., Ugalde, U.O., 1995: Proton production and consumption pathways in yeast metabolism. A chemostat culture analysis. Yeast, 11(14): 1353-1365.

Collar, C., Bollain, C., Angioloni, A., 2005: Significance of microbial transglutaminase on the sensory, mechanical ands crumb grain patters of enzyme supplemented fresh pan breads. J. Food Engn., 70(4): 479-488.

Das, J., Timm, H., Busse, H.-G., Degn, H., 1990: Oscillatory CO2 evolution in glycolysing yeast extracts. Yeast, 6: 255-261.

Debourg, A., 2002: Yeast in action: from wort to beer. Cerevisia Belgian J. Brew. Biotechnol., 27(3): 144-154.

de Maranon, I.M., Tourdot-Marechal, R., Gervais, P., 2001: Involvement of osmotic cell shrinkage on the proton extrusion rate in Saccharomyces cerevisiae. Int. J. Food Microbiol., 67(3): 241-246.

Dinsdale, M.G., Lloyd, D., Jarvis, B., 1995: Yeast vitality during cider fermentation: two approaches to the measurement of membrane potential. J. Inst. Brew. 101: 453-458.

Dinsdale, G., Lloyd, D., Mclntyre, P., Jarvis, B., 1999: Yeast vitality during cider fermentation: assessment by energy metabolism. Yeast, 15: 285-293.

Eide, D.J., Clark, S., Nair, T.M., Gehl, M., Gribskov, M., Guerinot, M.L., Harper, J.F., 2005: Characterization of the yeast ionome: a genome-wide analysis of nutrient mineral and trace element homeostasis in Saccharomyces cerevisiae. Genome Biol., 6(9): R77.

Fernandez, S.S., Gonzales, M. G., Sierra, J.A., 1991: The acidification power test and the behaviour of yeast in brewery fermentations. Tech. Q. Master Brew. Assoc. Am., 28(2): 28-95.

Fernandez, S.S., Gonzalez, M.G., Sierra, J.A., 1993: Evaluation of the effect of acid washing on the fermentative and respiratory behavior of yeasts by the acidification power test. Tech. Q. Master Brew. Assoc. Am., 30(2): 1-8.

Gabriel, P., Dienstbier, M., Matoulková, D., Kosař, K., Sigler, K., 2008: Optimised acidification power test of yeast vitality and its use in brewing practice. J. Inst. Brew., 114(3): 270-276.

Gatto, E., Peddie, F., Andrews, S., 1993: Acidification power: performance evaluation of freeze-dried lactic acid bacteria. Food Australia, 45(3): 124-128.

Hammond, J., Davis, D., Lee, M., Storey, K., 2001: Does osmotic pressure affect yeast performance in high gravity fermentation? Proc. Eur. Brew. Convention, Budapest: 316-325.

Higgins, V.J., Bell, P.J.L., Dawes, I.A., Attfield, P.V., 2001: Generation of a novel Saccharomyces cerevisiae strain that exhibits strong maltose utilization and hyperosmotic resistance using nonrecombinant techniques. Appl. Environ. Microbiol., 67(9): 4346-4348.

Imai, T., Nakajima, I., Ohno, T., 1994: Development of a new method for evaluation of yeast vitality by measuring intracellular $\mathrm{pH}$. J. Am. Soc. Brew. Chem., 52(1): 5-8.

Imai, T., 1999: The assessment of yeast vitality - the past and the future. Brewer's Guardian, 20-27.

Internatl. Dairy Federation, 1995: IDF Guideline: determination of acidifying activity of dairy cultures. Bull. Int. Dairy Fed., 306: 3436.

Iserentant, D., Geenens, W., Verachtert, H., 1996: Titrated acidification power: A simple and sensitive method to measure yeast vitality and its relation to other vitality measurements. J. Am. Soc. Brew. Chem., 54(2): 110-114.

Janda, S., Kotyk, A., 1985: Effect of suspension density on microbial metabolic processes. Folia Microbiol., 30: 465-473.

Jespersen, L., Jakobsen, M., 1994: Use of flow-cytometry for rapid estimation of intracellular events in brewing yeasts. J. Inst. Brew., 100(6): 399-403. al., 1996). The combinations of ethanol with either of the two other alcohols were found to act synergically to cause a pronounced decrease in viability and acidification power. These combinations are assumed to produce membrane lesions that adversely affect cider fermentation. Yeast repitching in cider fermentation (Dinsdale et al., 1995, 1999) brings about a considerable loss of vitality but a little loss of viability.

\section{Acknowledgements}

The work was supported by Institutional Research Concept RV061388971.

Jones, R.P., Greenfield, P.F., 1982: Effect of carbon dioxide on yeast growth and fermentation. Enzyme Microbiol. Technol. 4: 210-223.

Kara, B.V., Simpson, W.M., Hammond, R.M., 1988: Prediction of the fermentation performance of brewing yeast with the acidification power test. J. Inst. Brew., 94: 153-158.

Kondo, H., Yomo, H., Furukubo, S., Fukui, N., Nakatani, K., Kawasaki, Y., 1999: Advanced method for measuring proteinase $A$ in beer and application to brewing. J. Inst. Brew., 105(5): 293-300.

Lawrence, D.R., 2002: Brewing yeast fermentation performance. Int. J. Food Sci. Technol., 37(3): 337-338.

Machnicka, B., Grochowalska, R., Boniewska-Bernacka, E., Slonimska, L., Lachowicz, T.M., 2004: Acid excretion mutants of yeast Saccharomyces cerevisiae. Biochem. Biophys. Res. Comm., 325: 1030-1036.

Malfeito-Ferreira, M., Guerra, J.P.M., Loureiro, V., 1990: Proton extrusion as indicator of the adaptive state of yeast starters for the continuous production of sparkling wines. Am. J. Enol. Viticult., 41(3): 219-222.

Mathieu, C., Van den Bergh, L., Isenrentant, D., 1991: Prediction of yeast fermentation performance using the acidification power test. Proc. 23rd Eur. B $=$ Convention, Lisbon: 273-280.

Mitz, M.A., 1979: CDiodynamics: a new concept of cellular control. J. Theor. Biol., 80: 537-551.

Myers, A., Bourn, J., Poole, B., 2005: Glucose-induced acidification in yeast cultures. J. Biol. Educ., 40(1): 38-42.

Mochaba, F.M., O'Connor-Cox, E.S.C., Axcell, B.C., 1997: A novel and practical yeast vitality method based on magnesium ion release. J. Inst. Brew., 103(2): 99-102.

Mochaba, F., O'Connor-Cox, E.S.C., Axcell, B.C., 1998: Practical procedures to measure yeast viability and vitality prior to pitching. J. Am. Soc. Brew. Chem., 56(1): 1-6.

Opekarová, M., Sigler, K., 1982: Acidification power: Indicator of metabolic activity and autolytic changes in Saccharomyces cerevisiae. Folia Microbiol., 27: 395-403.

Oura, E., 1977: Reaction products of yeast fermentations. Process Biochem., 12: 19-21.

Pascual, C., Romay, Ch., Sigler, K., 1983: Proton extrusion in Sacharomyces cerevisiae mutants in very dilute suspensions. Folia Microbiol., 28: 353-362.

Patino, H., Edelen, C., Miller, J., 1993: Alternative measures of yeast vitality: Use of cumulative acidification power and conductance. J. Am. Soc. Brew. Chem., 51:128-132.

Pearce, L.E., 1969: Activity tests for cheese starter cultures. New Zealand J. Dairy Technol., 4: 246-247.

Peddie, F.L., Simpson, W.J., Kara, B.V., Robertson, S.C., Hammond, J.R.M., 1991: Measurement of endogenous oxygen uptake rates of brewer's yeast. J. Inst. Brew., 97: 21-25.

Quain, D.E., 1988: Studies on yeast physiology - impact on fermentation performance and product quality. J. Inst. Brew., 89: 38-40.

Rechinger, K.B., Siegumfeldt, H., 2002: Rapid assessment of cell viability of Lactobacillus delbrueckii subsp. bulgaricus by measurement of intracellular $\mathrm{pH}$ in individual cells using fluorescence ratio imaging microscopy. Int. J. Food. Microbiol., 75: 53-60.

Riis, S.B., Pedersen, H.M., Sorensen, N.K., Jakobsen, M., 1995: Flow cytometry and acidification power test as rapid techniques for determination of the activity of starter cultures of Lactobacillus delbrueckii ssp. bulgaricus. Food Microbiol., 12: 245-250.

Rodrigues, P.G., Barros, A.A., Rodrigues, J.A., Ferreira, A.A., Goncalves, C., Hammond, J.R.M., 2003: Yeast quality control in industrial brewing process using vitaltitration, a new method for vitality 
determination. Proc. 29th Int. C. Eur. Brew. Conv., Dublin, Ireland: Contribution 57.

Sami, M., Ikeda, M., Yabuuchi, S., 1994: Evaluation of the alkaline methylene-blue staining method for yeast activity determination. J. Ferm. Bioengn., 78(3): 212-216.

Semjonovs, P., Marauska, M., Linde, R., Grube, M., Zikmanis, P., Bekers, M., 2004: Development of Bifidobacterium lactis Bb 12 on beta-(2,6)-linked fructan-containing substrate. Engn. in Life Sci., 4(5): 433-437.

Seward, R., Willetts, J.C., Dinsdale, M.G., Lloyd, D., 1996: The effects of ethanol, hexan-1-ol, and 2-phenylethanol on cider yeast growth, viability and energy status; Synergistic inhibition. J. Inst. Brew., 102(6): 439-443.

Shen, H.Y., Moonjai, N., Verstrepen, N., Delvaux, F.R., 2003: Impact of attachment immobilization on yeast physiology and fermentation performance. J. Am. Soc. Brew. Chem., 61(2): 79-87.

Shindo, S., Takahashi, S., Kobayashi, M., 2000: A novel method for the determination of freshness of rice by acidification power test. J. Japan. Soc. Food Sci. Technol., 47(3): 260-263.

Sigler, K., Höfer, M., 1991a: Mechanisms of acid extrusion in yeast. Biochim. Biophys. Acta, 1071: 375-391.

Sigler, K., Höfer, M., 1991b: Activation of the plasma membrane H+-ATPase of Saccharomyces cerevisiae by addition of hydrogen peroxide. Biochem. Int., 23: 861-873.

Sigler, K., Höfer, M., 1997: Biotechnological aspects of membrane function. Critical Rev. Biotechnol., 17(2): 69-86. CRC Press, Boca Raton.

Sigler, K., Knotková, A., Kotyk A., 1981a: Factors governing substrate-induced generation and extrusion of protons in the yeast $\mathrm{Sa}$ ccharomyces cerevisiae. Biochim. Biophys. Acta, 643: 572-582.

Sigler, K., Kotyk, A., Knotková, A., Opekarová, M., 1981b: Processes involved in the creation of buffering capacity and in substrate-induced proton extrusion in the yeast Saccharomyces cerevisiae. Biochim. Biophys. Acta, 643: 583-592.

Sigler, K., Matoulková, D., Dienstbier, M., Gabriel, P., 2009: Net effect of wort osmotic pressure on fermentation course, yeast vitality, beer flavor and haze. Appl. Microbiol. Biotechnol., 82(6): 1027-1035.
Sigler, K., Pascual, C., Romay, Ch., 1983: Intracellular control of proton extrusion in Saccharomyces cerevisiae. Folia Microbiol., 28: 363-370.

Smart, K.A., Chambers, K.M., Lambert, I., Jenkins, C., Smart, C.A., 1999: Use of methylene violet staining procedure to determine yeast viability and vitality. J. Am. Soc. Brew. Chem., 57(1): 18-23.

Šusta, J., Hodaň, J., Opekarová, M., Sigler, K., 1984: A simple method for determining the metabolic activity of brewer's yeast during the brewing process. Food Microbiol., 1: 169-171.

Tsukatami, T., Ide, S., Oba, T., Ukeda, H., Matsumoto, K., 2003 Electrochemical measurement of yeast cell density and vitality using 2,3,5-trimethyl-1,4-benzoquinone and effect of ethanol on the metabolism of quinone by yeast cells. Food Sci. Technol. Res., 9(3): 271-275.

Van Zandycke, S.M., Siddique, R., Smart, K.A., 2001: Yeast membrane potential and carbohydrate utilisation. Proc. Eur. Brew. Conv., Budapest: 334-343.

Vincent, S.F., Bell, P.J.L., Bissinger, P., Nevalainen, K.M.-H., 1999: Comparison of melibiose utilizing baker's yeast strains produced by genetic engineering and classical breeding. Lett. Appl. Microbiol., 28: 148-152.

Wackerbauer, K., Ludwig, A., Mohle, J., 2002: Improvement of long term stability in main fermentations with immobilized yeast - II. Trials in MPI-reactor and evaluation of yeast vitality in the immobilized system. Monatsschr. Brau., 55(9): 172-181.

Willetts, J.C., Seward, R., Dinsdale, M.G., Suller, M.T.E., Lloyd, D., 1997: Vitality of cider yeast grown micro-aerobically with added ethanol, butan-1-ol or isobutanol. J. Inst. Brew., 103(2): 79-84.

Yoshikawa, S., Chikara, K.I., Hashomoto, H., Mirsui, N., Shimosaka, M., Okazaki, M., 1995: Isolation and characterization of Zygosaccharomyces rouxii mutants defective in proton pumpout activity and salt tolerance. J. Ferment. Bioengn., 79(1): 6-10.

Yu, Z., Zhao, H., Wan, Ch., Sun, G., Zhao, M., 2011: The dynamic changes of proton efflux rate in Saccharomyces pastorianus strains during high gravity or very high gravity brewing. J. Inst. Brew., 117(2): 176-181.

Do redakce došlo / Manuscript received: 17.04.2013 Prijiato k publikování / Accepted for publication: 09.06.2013

\section{5.

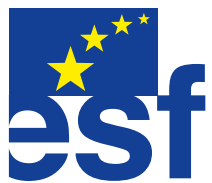

evropský sociální fond v ČR

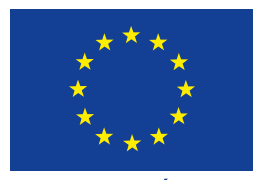

EVROPSKÁ UNIE

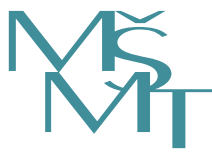

MINISTERSTVO ŠKOLSTVÍ, MLÁDEŽE A TĚLOVÝCHOVY

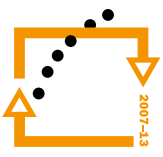

OP Vzdělávání pro konkurenceschopnost 